\title{
Obituary: Rev. Canon Professor Emeritus John Samuel Pobee (1937-2020)
}

\author{
J. Kwabena Asamoah-Gyadu \\ Trinity Theological Seminary, Legon, Ghana \\ kwabena.asamoahgyadu@gmail.com
}

\begin{abstract}
Right up to 1950 when I entered Adisadel College [Anglican mission boys' high school in Cape Coast, Ghana], I lived a life from one ailment to another. In the mysterious ways of the Almighty Creator God, the foregoing story did not stunt my life from what I became - an academic with some reputation, a priest, even becoming a vicar general and respected in the Anglican and Ecumenical world. All that filled me with a sense of grace ... and divine mercy. Against the foregoing, it is my wish and plea that the theme of divine mercy should be the undergirding theme of whatever is done to mark my exit.
\end{abstract}

These were words written by John S. Pobee and printed in the first page of the brochure put together to celebrate his funeral in Ghana on Thursday, February 13, 2020. Professor Pobee was a scholar of international repute, appointed emeritus professor at the University of Ghana, Legon, in 2000, consultant to the 1998 Lambeth Conference, a fellow of the Ghana Academy of Arts and Sciences, and a former president of the International Association of Mission Studies (IAMS), 1988 to 1992. In 2004 he was made an honorary life member of IAMS in "tribute to outstanding accomplishments in missiology and dedicated services" to the association. That both the President of the Republic of Ghana, Nana Addo Dankwa Akufo-Addo and the Vice President Mahamudu Bawumia were at his funeral was an indication of the national appreciation that Pobee attracted for his life's work.

Pobee studied for a Bachelor of Divinity degree at the University of Ghana from 1957 to 1961 that was awarded by the University of London. That meant 
he was in the initial group of young Africans in whom the new nation vested great hopes that they would be educated, mentored and equipped to run the affairs and institutions of the country in the immediate aftermath of Ghana's independence from British colonial rule in March 1957. Pobee did not disappoint in that respect.

After undergraduate studies, Pobee proceeded to Selwyn College, Cambridge, UK to undertake New Testament studies as part of the African faculty development program of the University of Ghana. At Cambridge, he won the Howard Prize for Theology following his studies under some distinguished professors including C.F.D. Moule, Ernst Bammel, John Sweet, William H.C. Frend and Geoffrey W.H. Lampe. Pobee's immediate mentor and college master, was the great church historian, Owen Chadwick. His graduate thesis was published in The Library of New Testament Studies in 1984 as Persecution and Martyrdom in the Theology of Paul. That was a landmark publication from an African scholar and spoke volumes about Pobee's stature as a theologian. A presentation he made in Cambridge as a graduate student was included in a 1969 festschrift for Prof. Moule.

Pobee returned to the University of Ghana in 1966 where he served as lecturer in the new Department for the Study of Religions, rising to become head of department and later dean of the Faculty of Arts. Additionally, he served as a visiting scholar to numerous universities, seminaries, and ecumenical institutions. His contemporaries then were Kwesi A. Dickson and Christian G. Baëta, both of blessed memory. In 1976, Pobee edited a festschrift titled Religion in a Pluralistic Society to honor Professor Baëta (Leiden: Brill). This book boasts essays from stalwarts like Andrew F. Walls. It is in that volume that Walls initially spoke about the shift in Christianity's center of gravity from the Northern to the Southern continents, and in a prophetic manner, laid out the full implications of that development for world Christianity in the twenty-first century. In 1979, Pobee became one of the pioneering African voices of theological contextualization with his book Toward an African Theology (Nashville, TN: Abingdon).

Pobee was introduced to the World Council of Churches (WCC) in 1972 by the now Archbishop Emeritus Desmond Tutu. The encounter with Desmond Tutu led to Pobee's membership of the Commission for the Theological Education Fund, of which he became associate director in 1983. He served as coordinator of Ecumenical Theological Education until 1998. Pobee dutifully dedicated his last monograph, Giving Account of Faith and Hope in Africa to Leah and Desmond Mpilo Tutu (Eugene, OR:Wipf and Stock, 2017). His contemporaries at the WCC included Mercy Amba Oduyoye, the uncontested "matriarch" of African women's theology and founder of the Circle of Concerned African Women Theologians. In his autobiography, Sense of Grace and Mission (Accra: 
Amanza, 2012), Pobee acknowledged that the spirit of ecumenism was birthed in him through the encounter with the WCc. In those fifteen years in Geneva, Pobee taught at the Ecumenical Theological Institute in Bossey, where he also served as academic dean.

Pobee trained for the Anglican priesthood at Westcott House, Cambridge but he delayed ordination until 1988. In July 1994, he married a Ghanaian diplomat Martha, who coincidentally, was a former student of his at the University of Ghana. At the time of Pobee's death, Martha was still serving as Ghana's permanent representative to the $\mathrm{UN}$ and the staff celebrated him in their tribute for the support that he gave Martha as a "diplomatic husband."

With Pobee's demise, the world of Christian scholarship has lost a theologian, author, ecumenist, missiologist and priest. In 2014, a group of his former students and colleagues in the theological academy prepared a festschrift in his honor titled, Trajectories of Religion in Africa (Cephas N. Omenyo and Eric B. Anum, eds.; Leiden: Brill). He consistently served as mentor and teacher to younger African scholars. In his writings, Pobee formulated theological paradigms that are deeply rooted in the African worldview. He focused his writings on church and state in Ghana and on current developments within the African public sphere as they affect religious life and engagements. Here is an extract from his memoirs:

Even before I turned seventy, I began a conscious drive to the end. I took voluntary, early retirement from Geneva, so as to be able to return to give something back to Ghana, after acquiring new experiences over the previous fifteen years in Geneva. I wrote my Will so as not to leave any confusion on my exit. I went further to compose my funeral service ... In our culture, death is not something you prepare for, let alone speak about ... [yet] I remain unrepentant that "here is no continuing city, here is not abiding stay" and therefore, one must boldly and faithfully march toward that promise of "a city beyond."

Sense of Grace and Mission, pp. $365^{-66}$, italics and bold in original

May the soul of the Rev. Canon Emeritus Professor John Samuel Pobee rest in peace, and may his impressive social, ecclesial and academic heritage be preserved to the glory of God and the blessing of generations. 